$\begin{array}{r}\text { Phinisi Integration Review } \\ \text { Vol. 1, No.2, Agustus 2018 Hal 216-222 } \\ \text { Website: } \underline{\text { http://ojs.unm.ac.id/pir }} \\ \hline- \\ \text { p-ISSN: 2614-2325 dan e-ISSN: 2614-2317 } \\ \hline\end{array}$

\title{
Peran Perempuan Single Parent Dalam Mengasuh Anak Di Kecamatan Maritengngae Kabupaten Sidrap (Suatu Kajian Antropologi Gender).
}

\author{
Dyan Paramitha \\ Pendidikan Antropologi, Program Pascasarjana, Universitas Negeri Makassar \\ Email: dyanparamitha@gmail.com
}

\begin{abstract}
Abstrak. Penelitian ini bertujuan untuk (1) Untuk mengetahui perubahan peran perempuan single parent (2) Untuk mengetahui alokasi waktu perempuan single parent pada ranah domestik dan ranah publik (3) Untuk mengetahui pola asuh yang diterapkan oleh perempuan single parent. Jenis penelitian ini adalah kualitif. Teknik pengumpulan data yang digunakan adalah observasi, dokumentasi dan wawancara mendalam dengan melibatkan 7 orang informan. Dalam penelitian ini pemilihan informan menggunakan purposive sampling sedangkan teknik pengabsahan data yang digunakan adalah triangulasi sumber. Hasil penelitian menunjukkan bahwa (1) Perubahan yang terjadi pada perempuan single parent adalah mereka lebih bertanggung jawab terhadap anak-anak mereka, mereka merasa lebih disiplin serta tidak hanya terjadi perubahan peran tetapi juga perubahan pola pikir khususnya dalam mengambil suatu keputusan. (2) Cara alokasi waktu yang dilakukan oleh para perempuan single parent adalah mereka berusaha untuk mengerjakan pekerjaan domestik terlebih dahulu sebelum mengerjakan pekerjaan publiknya , begitu juga setelah mereka melakukan pekerjaan publik mereka akan kembali mengerjakan pekerjaan domestik. (3) Dalam mengasuh anak para perempuan single parent ini menggunakan pola asuh demokratis dan menanamkan nilai budaya Bugis yaitu berupa siri' serta mempertahankan lima hal lainnya yaitu assitinajang (kepatutan), sipakatau (saling menghargai), getteng (tegas dan konsisten), dan lempu (kejujuran) dalam kehidupan sehari-harinya.
\end{abstract}

Kata Kunci: Single Parent, Alokasi Waktu, Pola Asuh

Abstract. The study aims at examining (1) the change of roles of single parent women, (2) time allocation of single parent women in public domain and domestic domain, and (3) the parenting applied by sinle parent women toward their children. The type of this study is descriptive qualitative. Data were collected by employing observation, documentation, and in-depth interview techniques by involving 7 infomants. In this study, the selection of informants used purposive sampling technique, and the data validation employed source triangulation. The result of the study reveal that (1) the changes in single parenrt women are as follows: they are more responsible on their children, they feel more discipline, and the change is not only in behaviour but also in mindset particularly in making decisions, (2) time allocations conducted by single parent women are as follows: they did the domestic first and public work afterwards: likewise, after they did the public work, they will return to their domestic work, and (3) in nurturing their children, the single parent women apply democratic parenting and insill cultural values of Buginese namely siri' and maintaining five aspects, namely assitinajang (decency), sipakatau (mutual respect), getteng (firm and consistent), dan lempu (honest) in daily lives.

Keyword: Single Parent, Time Allocation, Parenting. 


\section{PENDAHULUAN}

Partisipasi perempuan saat ini, bukan sekedar menuntut persamaan hak tetapi juga menyatakan fungsinya yang mempunyai arti bagi pembangunan dalam masyarakat Indonesia. Melihat potensi perempuan sebagai sumber daya manusia maka upaya menyertakan perempuan dalam proses pembangunan bukan hanya merupakan perikemanusiaan belaka, tetapi merupakan tindakan efisien karena tanpa mengikut sertakan perempuan dalam proses pembangunan berarti pemborosan dan memberi pengaruh negatif terhadap lajunya pertumbuhan ekonomi (Pudjiwati, 1983:23).

Partisipasi perempuan menyangkut peran tradisi dan transisi. Peran tradisi atau domestik mencakup peran perempuan sebagai istri, ibu dan pengelola rumah tangga. Sementara peran transisi meliputi pengertian perempuan sebagai tenaga kerja, anggota masyarakat dan manusia pembangunan. Pada peran transisi wanita sebagai tenaga kerja turut aktif dalam kegiatan ekonomis (mencari nafkah) di berbagai kegiatan sesuai dengan keterampilan dan pendidikan yang dimiliki serta lapangan pekerjaan yang tersedia (Sukesi, 1991:65).

Kehidupan modern dan era pembangunan dewasa ini, wanita dituntut dan sering termotivasi untuk mengembangkan karir dengan bekerja di luar rumah. Pada saat wanita menjalani karirnya, wanita juga dituntut untuk dapat berperan sebagai istri, serta ibu yang mengasuh dan merawat anak. Kaum perempuan berusaha untuk menyatukan karier dengan kehidupan keluarga, namun dalam prosesnya mereka seringkali menghadapi konflik dalam menyatukan urusan rumah tangganya dengan pekerjaannya. Masalah ini sering dialami oleh para perempuan pekerja yang mengutamakan keluarganya namun merasa sulit untuk melepaskan kariernya begitu saja.

Masalah peran ganda menyulitkan kedudukan perempuan pekerja di luar ranah domestik. Menurut Goode (Kaltsum, 2006:45), konflik peran ganda adalah kesulitan-kesulitan yang dirasakan dalam menjalankan kewajiban atau tuntutan peran yang berbeda secara bersamaan. Di mana, wanita bekerja dituntut untuk dapat menyelesaikan tugas-tugasnya baik di dalam keluarga, di kantor, sementara di sisi lain juga dituntut untuk dapat memberikan unjuk kerja (performance) yang maksimal. Hal ini dapat mempengaruhi motivasi kerja wanita untuk menyelesaikan tugas-tugas kantor.
Hurlock mengatakan bahwa tugas-tugas yang berkaitan dengan pekerjaan dan keluarga merupakan tugas yang sangat penting dan sulit, mereka harus melakukan penyesuaian diri dengan peran-peran tersebut (Hurlock, 2006:15). Hal ini menunjukkan bahwa perempuan dituntut untuk dapat melakukan penyesuaian diri terhadap peran-peran yang ada baik dalam ranah domestik dan ranah publik atau yang disebut dengan peran ganda. Peran ganda yang dilakukan oleh seorang perempuan tidak hanya

akan berpengaruh terhadap kehidupan perempuan peran ganda itu sendiri, tetapi juga akan sangat berpengaruh terhadap keluarganya.

Keluarga merupakan satuan unit terkecil dalam masyarakat, yang terdiri dari laki-laki dan perempuan yang disatukan melalui ikatan perkawinan. Laki-laki dan perempuan memutuskan untuk menikah dan membentuk keluarga dengan berbagai pertimbangan yang sudah dipersiapkan mereka berdua secara matang. Keluarga yang terdiri dari ayah, ibu, dan anak merupakan gambaran yang biasanya ada pada masyarakat.

Perceraian merupakan salah satu faktor penyebab banyaknya single parent di Indonesia. Jumlah perceraian semakin meningkat dari tahun ketahun. Indonesia merupakan salah satu negara dengan tingkat perceraian yang cukup tinggi. Data di Indonesia pada tahun 2005-2010 Badan Urusan Pengadilan Agama Mahkamah Agama mencatat angka perceraian di Indonesia meningkat hingga $70 \%$. Pihaknya tidak menyangkal terjadi kenaikan perceraian di atas 10 persen dibanding angka tahun 2010. Pada tahun 2010, terjadi 285.184 perceraian di seluruh Indonesia. Penyebab terjadinya perceraian ini akibat dari beberapa faktor yakni faktor ketidakharmonisan sebanyak 91.841 perkara, tidak ada tanggungjawab 78.407 perkara, dan masalah ekonomi 67.891 perkara. Data lain menyebutkan bahwa masih ada 7 juta orang wanita merupakan kepala keluarga. Penyebab hal ini beragam diantaranya perceraian dan kematian. Hal ini menunjukkan bahwa tingginya angka orang tua tunggal di Indonesia. (Kementrian pemberdayaan perempuan dan perlindungan anak berdayakan ekonomi keluarga 2012).

Hal di atas menunjukkan bahwa perceraian atau kematian merupakan salah satu faktor utama dalam suatu keluarga yang menyebabkan terjadinya ketidakseimbangan di dalam keluarga itu sendiri. Selain itu data yang diperoleh dari arsip pengadilan agama 
Kabupaten Sidrap tahun 2007, 2008 dan 2009 dalam Rasyid Ridha menunjukkan bahwa jumlah perempuan single parent di Kabupaten Sidrap sebanyak 1424 orang. Perempuanperempuan ini, membuktikan bahwa hidup tidak harus bergantung pada seorang laki-laki, hidup tidak harus ditangisi, serta hidup tidak harus dibelaskasihani. Kehidupan yang penuh tantangan ini, mereka lalui bersama pencitraan negatif sebagai perempuan yang ditinggal suami, di tengah persaingan dengan komunitas yang telah maju (Ridha, 2014: 6-7).

Lopata menyatakan bahwa, perbedaan utama yang terjadi pada seorang wanita ketika suaminya meninggal, tampaknya adalah apakah ia sendiri harus mengatur kembali sistem-sistem dukungan system dan gaya hidupnya, sebagaimana ciri khas wanita modern di pusatpusat perkotaan yang lebih berkembang, atau apakah integrasi sosialnya disediakan oleh orang-orang lain(1996:248). Dalam banyak masyarakat yang sedang mengalami transisi besar, suatu kesenjangan berkembang antara bagaimana wanita disosialisasikan dan bagaimana sekarang harus hidup. Kehidupan sehari-hari wanita berada dalam suatu konteks beban ganda.

Seorang perempuan yang menjadi seorang single parent tidak hanya akan memberikan pengasuhan dalam kehidupan rumah tangganya tetap juga memberikan nafkah bagi keluarganya, maka dari itu bisa saja terjadi konfilk peran jika salah satu peran yang dilakukan dengan baik tetapi salah satu peran diabaikan oleh karena kedua peran tersebut harus dilakukan sacara seimbang karena samasama membutuhkan waktu, tenaga dan juga perhatian.

Peran perempuan saat ini tidak lagi hanya sebagai seorang yang bekerja dalam ranah domestik saja tetapi kini telah berkembang juga menjadi seseorang yang juga bekerja dalam ranah pubilk. Perubahan yang terjadi pada seorang single parent yang awalnya menjadi seorang ibu dan istri kini berubah mejadi ibu sekaligus ayah yang tidak hanya mendidik, merawat, mengasuh anaknya tapi kini juga harus mencari nafkah keluarga tidak menyurutkan semangat perempuan single parent ini, mereka tetap melanjutkan dan memperbaiki hidupnya untuk kembali membangun keluarga secara harmonis.

Peran perempuan single parent sebagai kepala keluarga sangatlah penting, dimana ia akan melakukan tugas gandanya sebagai kepala keluarga yang memliki kewajiban untuk memenuhi kebutuhannya serta kebutuhan anakanaknya dan juga ia harus berperan sebagai seorang ibu yang mendidik anak-anaknya sekaligus juga melakukan pekerjaan rumah tangga. Perempuan single parent memiliki tanggung jawab yang sangat besar, selain wajib menyekolahkan anak-anaknya, memenuhi kebutuhannya ia juga sangat bertanggung jawab dalam menanamkan perilaku anak menjadi lebih baik juga etika-etika yang harus dimiliki oleh anak-anaknya hal inilah yang dilakukan oleh single parent di Kecamatan Maritengngae Kabupaten Sidrap. Sidrap merupakan salah satu daerah di Sulawesi Selatan yang memiliki jumlah janda atau single parent yang cukup banyak diantara daerah lainnya di Sulawesi Selatan terkhusus Kecamatan Maritengngae yang jumlah kasus cerai meninggal dan cerai talak mencapai hingga 200 kasus pada tahun 2016 dan ini terus meningkat setiap tahunnya hal inilah yang menjadi dasar mengapa penelitian ini dilakukan. Perempuan yang menjalani peran sebagai single parent bukanlah hal yang mudah tidak hanya harus bekerja di ranah publik untuk menggantikan peran suami sebagai pencari nafkah tetapi juga harus bekerja dalam ranah domestik sebagai ibu rumah tangga, selain itu mereka juga harus dapat mendidik anak-anaknya tanpa figur seorang suami. Mendidik anak sebagai status seorang single parent khusunya di Kecamatan Maritengngae Kabupaten Sidrap bukanlah hal yang mudah untuk dilakukan karena harus bertanggung jawab kepada anak sepenuhnya khususnya dalam tingkah laku anak oleh karena itu dibutuhkan pola asuh yang baik agar anak-anak juga mampu tumbuh dengan baik, maka dari itu penulis ingin mengetahui pola asuh yang diterapkan oleh perempuan single parent di Kecamatan Maritengngae Kabupaten Sidrap hingga anak-anak mereka bias bersekolah hingga pereguruan tinggi yang dimana di daerah Kabupaten Sidrap dianggap merupakan sesuatu hal yang membanggakan jika orang tua berhasil menyekolahkan anaknya hingga perguruan tinggi terlebih lagi jika ia merupakan orang tua tunggal atau seorang single parent.

Namun dalam penelitian ini penulis hanya akan mengambil dan membahas single parent atau seorang ibu yang bekerja dalam sektor publik dan sektor domestik untuk membiayai kehidupannya dan kehidupan anak anaknya karena kematian suaminya ini bertujuan agar penulis dapat mengetahui pola asuh 
seorang single parent yang tidak hanya mengasuh anak anaknya, tetapi juga membiayai anak-anaknya khususnya dalam pendidikan hingga jenjang perguruan tinggi. Seperti halnya perubahan peran serta beban tugas yang harus ditanggung untuk mengasuh anak. Pengasuhan single parent akan berimbas pada kepribadian anak. Banyaknya kasus single parent yang terjadi di Sidrap membuat peneliti ingin mengetahui lebih jauh bagaimana peran pengasuhan single parent di Sidrap terhadap kepribadian anak.

Berdasarkan seluruh uraian di atas, maka dalam penelitian ini penulis akan menjawab bagaimana perubahan perempuan yang menjunjung tinggi kesetaraan gender dengan memasuki ranah publik dan ranah domestik secara bersamaan , untuk menjawab bagaimana perempuan yang berperan ganda menyeimbangkan antara ranah publik dan ranah domestik dan juga untuk menjawab bagaimana pola asuh yang diterapkan perempuan single parent terhadap anak-anaknya, oleh karena itu penulis tertarik untuk membahas dan mencoba melakukan penelitian dengan judul peran perempuan single parent dalam mengasuh anak di Kecamatan Maritengngae Kabupaten Sidrap (suatu kajian antropologi gender).

Tujuan penelitian dari penelitian ini adalah: (1) Untuk mengetahui perubahan peran perempuan single parent yang hanya bekerja di ranah domestik kemudian berubah menjadi perempuan yang bekerja di ranah domestik juga ranah public. (2) Untuk mengetahui alokasi waktu perempuan single parent pada di ranah domestik dan ranah public. (3) Untuk mengetahui pola asuh yang diterapkan perempuan single parent terhadap anakanaknya. perempuan single parent dalam mengasuh anak di Kecamatan Maritengngae Kabupaten Sidrap (suatu kajian antropologi gender).

\section{METODE}

Peneliti akan menggunakan metode penelitian kualitatif deskriptif. Penelitian kualitatif adalah penelitian yang bermaksud untuk memahami fenomena tentang apa yang dialami oleh subjek penelitian, misalnya perilaku, persepsi, motivasi, tindakan, dan lainlain, secara holistik dan dengan cara deskripsi dalam bentuk kata-kata dan bahasa, pada suatu konteks khusus yang alamiah dan dengan memanfaatkan berbagai metode alamiah (Moleong, 2010:141). Adapun lokasi dalam penelitian ini bertempat di

Kecamatan

Maritengngae Kabupaten Sidrap, peneliti melakukan penelitian di lokasi ini karena berdasarkan observasi awal yang dilakukan oleh peneliti bahwa di daerah tersebut terdapat beberapa informan yang sesuai dengan karakteristik yang ingin dijadikan informan dalam penelitian ini.

Adapun yang menjadi teknik penentuan dan pengambilan sasaran penelitian yang disebut informan penelitian adalah secara purposive sampling. Purposive sampling adalah teknik pengambilan sampel sumber data dengan pertimbangan tertentu (Sugiyono, 2014:300). Adapun yang menjadi syarat informan dalam penelitian ini adalah perempuan yang merupakan single parent yang menjadi janda karena kematian suaminya, minimal lima tahun serta membesarkan anak-anaknya dengan tidak hanya bekerja dalam ranah domestik tetapi juga dalam ranah publik serta memiliki anak yang telah bersekolah hingga jenjang perguruan tinggi hal ini bertujuan untuk mengetahui bagaimana pola asuh yang diterapkan oleh informan dan bagaimana mengelola alokasi waktu dalam melakukan pekerjaan ranah publik serta pekerjaan domestik.

Adapun metode atau cara yang peneliti gunakan dalam pengumpulan data nantinya adalah pengamatan,wawancara mendalam dan dokumentasi sebagai berikut: Teknik Pengamatan (observation), Teknik Wawancara Mendalam (Depth-Interview),Dokumentasi. Selain metode diatas, peneliti juga menggunakan metode kajian literatur dan dokumentasi penelitian menggunakan alat bantu kamera. Kajian literatur atau dokumentasi yang di maksudkan penulis disini adalah peninggalan tertulis seperti arsip-arsip dan termasuk juga buku-buku, teori, dalil atau hukum-hukum, dan lain-lain yang termasuk dengan masalah penelitian. Metode analisis data adalah cara-cara untuk memilah-milah mengelompokkan data kualitatif maupun data kuantitatif agar kemudian dapat ditetapkan relasi-relasi tertentu antara kategori data yang satu dengan data yang lain (Heddy, 2007:29). Penulis menggunkan analisis melalui tiga tahapan kerja yang dikemukakan oleh Miles dan Huberman dalam Ahmadin sebagai berikut: (1) Reduksi Data, merupakan proses seleksi, pemfokusan, penyederhanaan dan abstraksi data. (2) Penyajian data, yaitu suatu rakitan organisasi informasi, deskripsi dalam bentuk narasi yang memungkinkan simpulan penelitian 
dapat dilakukan. (3) Penarikan kesimpulan, untuk menuju kearah ini, sejak awal pengumpulan data peneliti harus memahami apa arti dari berbagai hal yang ia temui dengan melakukan pencatatan peraturan-peraturan, pola-pola, pernyataan-pernyataan, konfigurasi yang mungkin, arahan sebab akibat dan berbagai proposisi (Ahmadin, 2013:109-110).

Dalam suatu penelitian perlu dikemukakan rencana uji keabsahan data yang akan dilakukan adalah uji keabsahan data triangulasi. Triangulasi diartikan sebagai pengecekan data dari berbagai sumber dengan berbagai cara, dan berbagai waktu (Sugiyono, 2014:369). Dengan demikian terdapat triangulasi sumber, triangulasi pengumpulan data, dan triangulasi waktu.

Namun dalam penelitian ini peneliti akan menggunakan salah satu dari tiga triangulasi uji keabsahan data, yaitu triangulasi sumber. Peneliti akan menggunakan tringulasi sumber karena peneliti akan membandingkan data hasil pengamatan dengan data hasil wawancara informan dan juga membandingkan hasil wawancara dengan isi suatu dokumen yang berkaitan.

\section{HASIL DAN PEMBAHASAN}

Kabupaten Sidenreng Rappang atau biasa dikenal dengan Kabupaten Sidrap, merupakan salah satu kabupaten di Propinsi Sulawesi yang terletak kira-kira $183 \mathrm{~km}$ di sebelah Utara Kota Makassar (Ibukota Propinsi Sulawesi Selatan). Secara astronomis, Kabupaten Sidrap terletak antara $3^{\circ} 43^{\prime}-4^{\circ} 09^{\prime}$ Lintang Selatan dan $119^{\circ} 41^{\prime}-120^{\circ} 10^{\prime}$ Bujur Timur, masing-masing berbatasan dengan sebelah utara : kabupaten Pinrang dan kabupaten Enrekang, sebelah timur : kabupaten Luwu dan kabupaten Wajo, sebelah selatan : kabupaten Barru dan kabupaten Soppeng sebelah barat : kabupaten Pinrang dan kota Pare-pare

\section{Hasil Penelitian}

\section{Perubahan Peran Perempuan Single Parent.}

Para perempuan yang melakukan pekerjaan di ranah domestik dan ranah publik secara bersamaan memiliki beberapa tujuan yaitu untuk memperluas pergaulan, memperluas pengetahuannya atau dengan kata lain menambah wawasan, dan tentu saja untuk mendapatkan penghasilan hal ini jugalah yang di lakukan oleh para perempuan single parent di
Kecamatan Maritengngae Kabupaten Sidrap. Perempuan single parent di Kecamatan Maritengngae Kabupaten Sidrap melakukan pekerjaan di ranah publik memiliki tujuan utama yaitu untuk mencari nafkah, untuk memenuhi kebutuhan hidupnya juga kebutuhan anak-anaknya.

Berdasarkan penelitian yang dilakukan adapun beberapa hal yang berubah pada perempuan single parent yaitu: Lebih bertanggung jawab, Lebih Disiplin, Lebih berhati-hati dalam mengambil keputusan.

\section{Alokasi Waktu Perempuan Single Parent}

Perempuan single parent yang dapat mengalokasikan waktunya dengan baik maka tidak akan mengalami terjadinya kelebihan beban kerja sedangkan perempuan yang mengalami kesulitan dalam mengalokasikan waktunya akan mengakibatkan kelebihan beban kerja seperti yang telah dijelaskan dalam BAB II mengenai alokasi waktu yang dimana menjelaskan bahwa perempuan yang bekerja seringkali mengalami kesulitan dalam membagi waktu antara pekerjaan di ranah publik dengan pekerjaan di ranah domestik. .Seorang perempuan yang memiliki beban ganda tidak hanya menyebabkan tekanan fisik maupun psikis tetapi juga akan menyebabkan konflik dalam pekerjaan ataupun dalam kehidupan rumah tangga.

Teori yang menurut peneliti juga dapat digunakan dalam mengkaji perempuan single parent di Kecamatan Maritengngae Kabupaten Sidrap adalah teori struktural fungsional. Teori struktural fungsional seperrti yang telah dijelaskan pada BAB II adalah suatu teori mencari unsur-unsur mendasar yang berpengaruh di dalam suatu masyarakat, mengidentifikasi fungsi Setiap unsur, dan menerangkan bagaimana fungsi unsur-unsur tersebut dalam masyarakat atau dapat juga dikatakan sebagai suatu teori yang saling mempengaruhi antara struktur dan fungsi dalam suatu susunan masyarakat dalam hal ini adalah keluarga. Keluarga seperti yang kita ketahui khususnya dalam keluarga inti memiliki struktur yaitu ayah, ibu dan anak dimana ayah berperan untuk mencari nafkah dan ibu berperan sebagai yang mengurus rumah tangga namun pada kenyataannya dalam penelitian ini saat struktur seorang ayah sebagai pencari nafkah tidak ada agar tetap berlansungnya kehidupan dalam keluarga perlu ada yang harus menambah peran atau juga menjadi struktur figur seorang ayah 
untuk mencari nafkah yaitu ibu agar fungsi fungsi yang lainnya tetap berjalan baik dan tidak menganggu fungsi yang satu dengan yang lainnya. Peran ibu dalam hal ini tidak hanya harus menjadi seorang ibu yang mengurus urusan rumah tangga, mengurus anak tetapi juga harus mencari nafkah hal inilah yang mengharuskan para perempuan single parent di Kecamatan Maritengngae Kabupaten Sidrap ini untuk mampu mengalokasikan waktunya dengan baik agar tidak terjadi konflik.

\section{Pola Asuh Perempuan Single Parent}

Budaya merupakan salah satu faktor yang mempengaruhi pola asuh seorang anak, karena seorang anak akan menjadi pribadi yang berkarakter apa bila ia tumbuh di lingkungan yang berkarakter. Pada dasarnya setiap etnis memiliki cara-cara atau pedoman tersendiri dalam berperilaku untuk membantuk karakter seorang anak, misalnya dalam suku Bugis. Dalam pembahasan mengenai pola asuh kali ini peneliti akan membahas mengenai pola asuh yang ditanamkan oleh para perempuan single parent di Kecamatan Maritengngae Kabupaten Sidrap . Telah dijelaskan pada bab sebelumnya bahwa batasan pola asuh yang digunakan dalam penelitian ini adalah pola asuh menurut Kohn (dalam Thoha, 1996:110) yang dimana pola asuh merupakan sikap orang tua dalam berhubungan dengan anaknya. Sikap ini dapat dilihat dari berbagai segi, antara lain dari cara orang tua memberikan pengaturan kepada anak, cara memberikan hadiah dan hukuman, cara orang tua menunjukkan otoritas dan cara orang tua memberikan perhatian, tanggapan terhadap keinginan anak. Dengan demikian yang dimaksud dengan Pola Asuh Orang Tua adalah bagaimana cara mendidik anak baik secara langsung maupun tidak langsung.

Dalam suku Bugis dikenal adanya Pangaderreng. Pangaderreng adalah sistem norma dan aturan-aturan adat.. Dalam pangadarreng sendiri terdapat nilai siri'. Siri adalah suatu hal bagi seseorang agar tidak melakukan pelanggaran ade' sementara nilainilai harga diri atau martabat menuntut seseorang untuk selalu patuh dan hormat pada kaidah-kaidahade' (hukum). Hal ini terungkap dalam petuah-petuah atau pasen-pasen. Pola pengasuhan anak dalam keluarga Bugis memperlihatkan kurang lebih adanya kesamaan dengan nilai Islam dan nilai budaya Bugis. Single parent di Kecamatan Maritengngae tidak hanya menanamkan konsep siri' yaitu menjunjung tinggi harga tinggi dan nama baik keluarga dimanapun ia berada tetapi juga menamkan nilai-nilai seperti seperti assitinajang (kepatutan), sipakatau (saling menghargai), getteng (tegas dan konsisten), dan lетри (kejujuran). Dengan cara otoritas orang tua seperti inilah anak-anak akan mengerti dan lebih memahami maksud serta tujuan dari sifat otoritas orang tuanya. Anak-anak akan mengerti serta menyadari apa yang benar, bagaimana harusnya bersikap, mengetahui hak dan kewajiban yang harus ia lakukan dan orang tua juga dapat memberikan hak pada anaknya namun dengan tetap memberikan batasan yang jelas dan tegas. Para perempuan single parent ini biasanya menasehati anaknya saat lagi ingin tidur khususnya terhadap anak perempuannya karena ia menganggap bahwa dengan cara itu anaknya lebih memungkinkan untuk dapat menerima nasehat dari ibunya.

Nilai agama dan nilai budaya Bugis yang diterapkan oleh para perempuan single parent di Kecamatan Maritengngae Kabupaten Sidrap ini dalam menunjukkan otoritasnya mampu mempengaruhi anak-anaknya. Anak secara tidak lansung menyadari mengenai hal yang benar serta hal yang salah dalam berbagai sudut pandang agama dan budaya dalam bertindak melakukan sesuatu namun dengan tetap memberikan batasan yang tegas serta jelas dari orang tua. Selain itu para perempuan single parent ini dalam memberikan nasihat atau cara dia menunjukkan otoritasnya seringkali ia mengatakan dan menjelaskan statusnya sebagai seorang single parent terhadap anaknya dengan begitu anaknya jauh lebih mengerti dan lebih sadar akan kondisi ibunya yang secara tidak lansung mempengaruhi anak untuk selalu melakukan yang terbaik khususnya untuk ibunya.

\section{SIMPULAN DAN SARAN}

Berdasarkan hasil peneilitian dan pembahasan, maka dapat ditarik beberapa kesimpulan sebagai berikut ; (1) Perubahan peran yang terjadi pada perempuan single parent yang awalnya merupakan hanya seseorang perempuan yang bekerja di ranah domestik kemudia bekerja di ranah domestik dan ranah publik adalah para perempuan single parent merasa mereka lebih bertanggung jawab terhadap anak-anak mereka, mereka merasa lebih disiplin dan terdapat perubahan pola pikir khususnya dalam mengambil kepuitusan. (2) Cara alokasi waktu yang dilakukan oleh para perempuan single parent di Kecamatan 
Maritengngae Kabupaten Sidrap adalah mereka berusaha untuk mengerjakan pekerjaan domestik terlebih dahulu sebelum mengerjakan pekerjaan publiknya, begitu juga sebaliknya (3) Dalam mengasuh anak para perempuan single parent di Kecamatan Maritengngae Kabupaten Sidrap lebih cenderung menggunakan pola asuh demokratis

Sehubungan dengan kesimpulan di atas, maka penulis ingin mengemukakan saran-saran sebagai berikut: Para perempuan single parent di Kecamatan Maritengngae Kabupaten Sidrap ini sebaiknya mampu beradaptasi dengan keadaan dan tanggung jawabnya saat ini sebagai orang tua tunggal selain itu juga berhati-hati dalam mengambil keputusan khususnya mengenai anak karena hampir semua keputusan dipengaruhi oleh single parent di Kecamatan Maritengngae Kabupaten Sidrap ini. Bagi para perempuan single parent di Kecamatan Maritengngae Kabupaten Sidrap yang bertanggung jawab melakukan pekerjaan dalam ranah domestik dan juga melakukan pekerjaan dalam ranah publik selain itu tanggung jawabnya kepada dirinya sendiri haruslah mampu membagi waktu dengan baik dan tetap memperhatikan kesehatan dan waktu istirahat yang cukup saat ia sedang berada dalam ranah domestiknya agar ia dapat dengan baik menjalankan tugasnya sebagai perempuan perempuan single parent. Perlu ditanamkan lagi nilai-nilai budaya Bugis lebih banyak dalam mengasuh anak-anak agar anak-anak terbiasa dan memiliki kepribadian yang baik dan mampu juga diterima dengan baik dalam lingkungan masyarakat.

\section{DAFTAR RUJUKAN}

Ahmad, Abu \& Uhbiyatu, Nur. 2001. Ilmu Pendidikan. Jakarta: Rineka Cipta Ahmadin. 2013. Metode Penelitian Sosial. Makassar: Rayhan Intermedia.

Hurlock. 2006. Psikologi Perkembangan: Suatu Pendekatan Sepanjang Rentang Kehidupan.

Jakarta: Erlangga.

Departemen Pendidikan dan Kebudayaan. Nugroho, Rian. 2012. Gender dan Strategi Pengaruh Utamanya di Indonesia. Yogyakarta: Pustaka Pelajar.

Ratna Saptari. 1997. Wanita, Kerja dan Perubahan Sosial Sebuah
Pengantar Studi Wanita. Jakarta: PT Anem Kosong Anem.

Rauf, Rabihatun . 2008. Angkatan Kerja Wanita Kasus Tiga Kota di Sulawesi Selatan. Makassar: Rayhan Intermedia.

Ridha, Rasyid. 2014. Jangan Takut Jadi Janda (Jejak Sukses Perempuan Pedagang di Sidenreng Rappang). Makassar: Rayhan Intermedia.

Ritzer, George. 2012.Teori Sosiologi Modern. Jakarta: Penerbit Kencana. Sadli, Saparinah. 2010. Berbeda Tetapi Setara- Pemikiran Tentang Kajian Perempuan. Jakarta: Kompas.

Sajogyo, Pudjiwati. 1983. Peranan wanita dalam Perkembangan Masyarakat Desa (The Role of Women in Developing Village Society). Jakarta: CV. Rajawali.

Sugiyono. 2014. Metode Penelitian Kombinasi.

Bandung : Penerbit Alfabeta. Suratman. 2000. Kamus Lengkap Psikologi. Jakarta: Rineka Cipta.

Thoha, Miftah. 1996.Perilaku Organisasi.

Jakarta: PT Gramedia Pustaka Utama. Tong, Rosemarie Putnam. 2010. Feminist Thought: Pengantar Paling Komprehensif kepada Aliran Utama Pemikiran Feminis. Yogyakarta: Jalasutra.

Heddy Shri. Paradigma, Epistemologi, dan Metode Ilmu Sosial-Budaya. (Makalah disampaikan dalam pelatihan "Metodologi Penelitian" diselenggarakan oleh CRCSUGM di Yogyakarta, 12 Februari 2007-19 Maret 2007).

Sukesi, Keppi. 1991. Status dan Peranan Perempuan: Apa Implikasinya Bagi Studi Perempuan dalam Warta Studi Perempuan. Vol. 2 No 1. Jakarta: PDII-LIPI 